\title{
Sporobolus tetragonus (Poaceae: Chloridoideae), an addition to the flora of South India
}

\author{
Swamy J. ${ }^{1 *} \&$ S. Arumugam ${ }^{2}$ \\ ${ }^{1}$ Botanical Survey of India, Deccan Regional Centre, Hyderabad, Telangana - 500 095, India \\ ${ }^{2}$ Botanical Survey of India, Southern Regional Centre, Coimbatore, Tamil Nadu - 641 003, India \\ *E-mail: swamy.2706@gmail.com
}

\begin{abstract}
Sporobolus tetragonus Bor (Poaceae: Chloridoideae) is reported here as an addition to the flora of South India from the Eastern Ghats (Kinnerasani Wildlife Sanctuary) of Telangana, after fifty years of its last collection from the Jim Corbett National Park, Uttarakhand. A detailed description with photographs is provided to facilitate easy identification.
\end{abstract}

Keywords: Eastern Ghats, New record, Rediscovery, Telangana.

\section{Introduction}

The grass genus Sporobolus R.Br. (Poaceae, Chloridoideae) is represented by 180-222 species widely distributed in tropical and subtropical regions of the world (Peterson et al., 2017; POWO, 2021). The genus is represented in India by 18 species, of which only S. hajrae P.Umam. \& P.Daniel is endemic to the country (Arumugam, 2016).

While exploring the grasses of Telangana state, a small population of Sporobolus plants was observed in the Kinnerasani Wildlife Sanctuary (Eastern Ghats) and a few voucher specimens were collected from the existing populations by the first author. On critical taxonomic studies using the relevant literature (Bor, 1960; Karthikeyan et al., 1989; Sreekumar \& Nair, 1991; Moulik, 1997; Kabeer \& Nair, 2009; Arumugam et al., 2018; Prasanna, 2019), these specimens were identified as $S$. tetragonus Bor. The species has been recorded from Bihar, Jharkhand and Uttarakhand states (Arumugam,

Received: 01.09.2020; Revised \& Accepted: 03.08.2021

Published Online: 31.12.2021
2016; Arumugam et al., 2018), but not from South India. Hence, the present collection forms the first report of this species in South India. A detailed description with photographs is provided to facilitate easy identification. Voucher specimens are deposited at the Botanical Survey of India, Deccan Regional Centre (BSID), Hyderabad, Telangana.

\section{Taxonomic Treatment}

Sporobolus tetragonus Bor, Kew Bull. 4(2): 251.1949, Grasses Burma, Ceylon, India \& Pakistan 633.1960. Lectotype (designated by Arumugam et al., 2018): SIAM [THAILAND], Kanburi, 19.10.1930, A.F.G. Kerr 19762 (K [K000290399 digital image!]; isolecto (K [K000290400 digital image!]).

Fig. 1

Annuals. Culms erect, 35-60 cm high; nodes c. 0.25 $\times 1.04 \mathrm{~mm}$, glabrous; internodes $2-7 \mathrm{~cm}$ long. Leaf blades linear-lanceolate, 2-11 × $0.4-0.6 \mathrm{~cm}$, flaccid, surface rough on both sides, scabrous at margins with tuberculate-ciliate hairs, apex acuminate, base rounded, hairy; ligule with a fringe of hairs, c. 0.76 $\times 1.25 \mathrm{~mm}$; leaf sheaths $1-5.5 \times 0.4-0.7 \mathrm{~cm}$, glabrous, upper ones tightly clasping, lower loose. Inflorescence an open panicle, elliptic, effuse, 8-25 $\times 2.5-8 \mathrm{~cm}$; primary branches whorled at most nodes and re-branched above the middle nodes, 2$4 \mathrm{~cm}$ long; branches smooth or scaberulous; peduncle terete, 6-24 cm long; pedicels 1-1.5 mm long, scaberulous. Spikelets solitary, lanceolate, $1.14-1.5 \times 0.57-0.8 \mathrm{~mm}$, pale green. Glumes deciduous, unequal, reaching apex of the florets; lower glume lanceolate, hyaline, 0.9-1.0 × 0.20- 

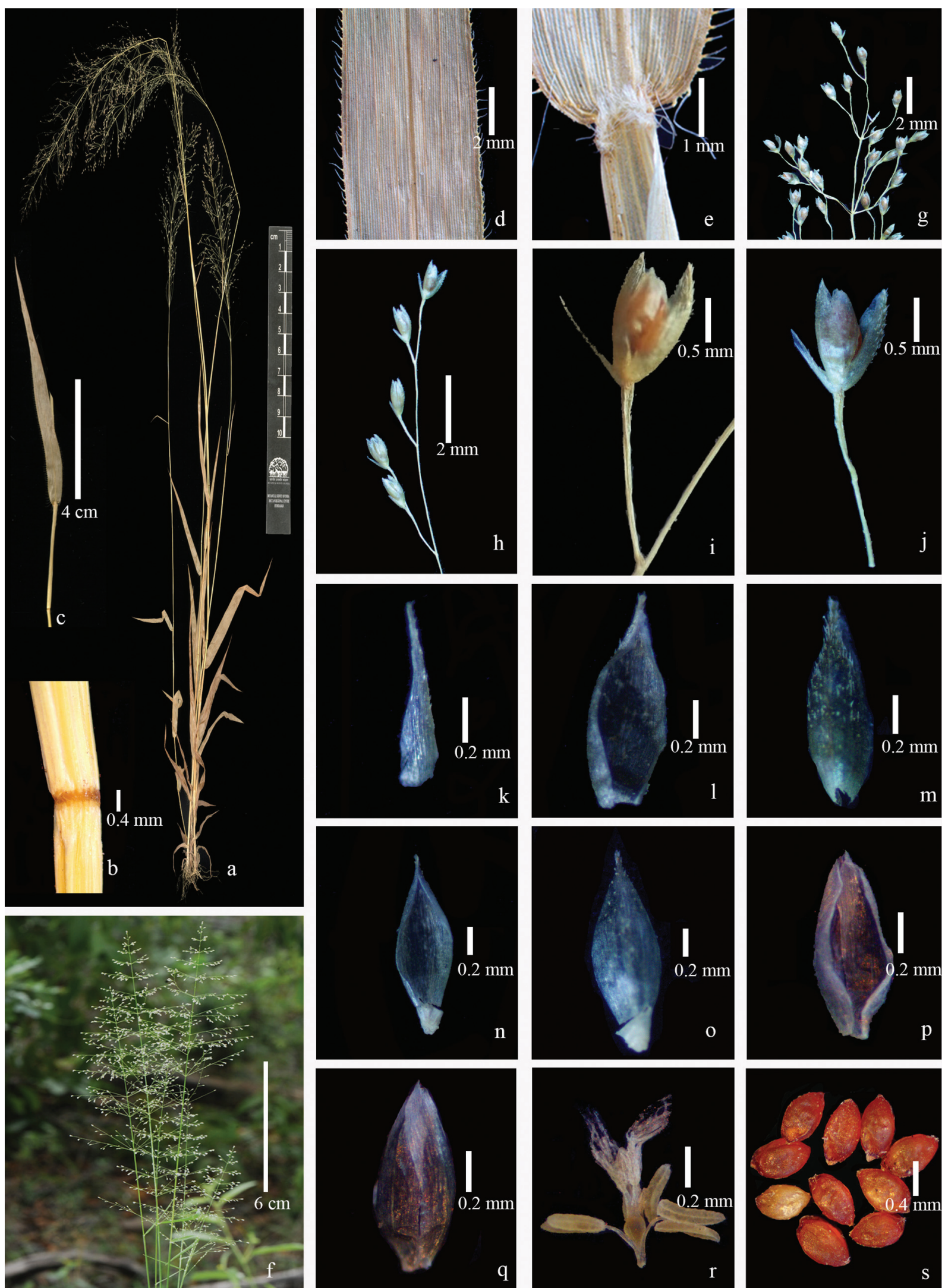

Fig. 1. Sporobolus tetragonus Bor: a. Habit; b. Node; c. Leaf; d. Mid portion of leaf blade; e. Ligule; f. Inflorescence; g. Portion of inflorescence; h. Portion of raceme; i-j. Spikelets; $\mathbf{k}$. Lower glume; I-m. Upper glume; $\mathbf{n}-\mathbf{0}$. Lemmas; $\mathbf{p}-\mathbf{q}$. Paleas; r. Pistil and stamens; $\mathbf{s}$. Caryopses (from J. Swamy 009805; photos by J. Swamy). 
$0.28 \mathrm{~mm}$ long, $1 / 2$ of the upper glume, nerveless, without keels, apex acute, scabrous, rough; upper glume elliptic, membranous, 1.33-1.6 × 0.47-0.7 mm, 1-nerved, keeled, apex acute, rough, scabrous above. Lemma elliptic, membranous, 1.23-1.6 × 0.4-0.5 mm, 1-nerved, without keel, apex obtuse or acute, scabrous on upper third part. Palea 0.9$1.4 \times 0.4-0.5 \mathrm{~mm}$, membranous, apex acute, 2veined. Stamens 3; anthers linear, c. $0.35 \mathrm{~mm}$ long, yellowish; filaments c. $0.2 \mathrm{~mm}$ long. Ovary elliptic, c. $0.2 \mathrm{~mm}$ long, yellowish green; style c. $0.18 \mathrm{~mm}$ long, pale greenish; stigma plumose, c. $0.5 \mathrm{~mm}$ long, pale greenish. Caryopsis ellipsoid, brownish, 0.67$0.8 \times 0.39-0.46 \mathrm{~mm}$, quadrangular with free soft pericarp.

Flowering \& fruiting: Flowering and fruiting from August to April.

Habitat: Occasional in open areas of dry deciduous forests. It grows in association with Adenosma indiana (Lour.) Merr. (Plantaginaceae), Mitracarpus hirtus (L.) DC. (Rubiaceae), and Osbeckia zeylanica L.f. (Melastomataceae).

Distribution: India, Myanmar, and Thailand.

Specimens examined: INDIA, Bihar, Monger, September 1811, Wallich 3764 (Wallich cat. No 8883 IDC, microfiche at MH). Jharkhand, Chota Nagpore, Ramghur ghat, 19.10.1883, C.B. Clarke 33908 (CAL). Telangana, Bhadradi Kothagudem district, Kinnerasani Wildlife Sanctuary, Allapally Range, Venkatapuram section, Yerragutta Beat, N 1751'37.008", E 80³3'55.583", 208 m.a.s.l., 30.09.2019, J. Swamy 009805 (BSID). Uttarakhand, Jim Corbett National Park, 11.11.1970, P.C. Pant 43141 (BSD).

Conservation status: The species is recorded from four states in India. The field observations in Telangana state revealed that the population had about 50 mature individuals within a $100 \mathrm{~m}^{2}$ (AOO) area in open grasslands. Forest dwellers of the area bring their cattle for grazing in this area, which is one of the major threats to the species. As this grass species is at present known from only a small patch in the Kinnerasani Wildlife Sanctuary in the Eastern Ghats region, it is threatened at the regional level. With less than five localities the species may be regarded as endangered (E), although the extent of occurrence is extensive. Since the situations of the known localities in other states and its presence in the intervening states is unclear, the species should be categorised at present as data deficient (DD) in India (IUCN, 2019).

Notes: Sporobolus tetragonus is often misidentified by many taxonomists with its closely allied species, S. capillaris Miq., S. coromandelianus (Retz.) Kunth, and S. ioclados (Nees ex Trin.) Nees, due to the nature of the inflorescences, small spikelets and minute caryopses. A key has been provided here to facilitate their easy identification. The authors have thoroughly checked Sporobolus specimens in various Indian herbaria (BSA, BSID, CAL, HY, KU and $\mathrm{MH}$ ) and found that some of the specimens of S. capillaris, S. coromandelianus and S. ioclados were wrongly identified as Sporobolus tetragonus. The latter species was last collected from India by P.C. Pant in 1970 from the Jim Corbett National Park, Uttarakhand. The present collection from the Eastern Ghats region represents a rediscovery of the species after a lapse of over 50 years. Besides, very few specimens of this species are available at Indian herbaria, clearly. Hence, this rare grass species only after its precise conservation status has been ascertained.

\section{Key to Sporobolus tetragonus and its allied species}

1. Inflorescence branches sub-whorled at proximal nodes, whorled at distal nodes only; inflorescence branches glandular .. 2

1. Inflorescence at proximal as well as distal nodes whorled; inflorescence branches eglandular 3

2. Spikelets elliptic-lanceolate, $1-1.3 \mathrm{~mm}$ long; lower glume ovate, $0.3 \mathrm{~mm}$ long

S. coromandelianus

2. Spikelets oblong-lanceolate, 1.5-1.8 mm long; lower glume lanceolate, c. $1 \mathrm{~mm}$ long S. ioclados 
3. Leaf surface glabrous; panicle ovate, up to 15 cm long; caryopsis obovoid, up to $0.6 \mathrm{~mm}$ long S. pulchellus

3. Leaf surface rough; panicle elliptic, up to 25 cm long; caryopsis ellipsoid, quadrangular, 0.67-0.8 mm long S. tetragonus

\section{Acknowledgements}

The authors are thankful to the Director, Botanical Survey of India (BSI), Kolkata; the Scientist Incharge, BSI, Deccan Regional Centre, Hyderabad and Scientist In-charge, BSI, Southern Regional Centre, Coimbatore for facilities and to the officials of Kinnerasani Wildlife Sanctuary, Telangana State Forest Department for permission and logistic support.

\section{Literature Cited}

ARUMUGAM S. 2016. A taxonomic study on the grass subtribe Sporobolinae Benth. (Tribe: Eragrostideae Stapf) in India. Ph.D. Thesis (unpublished), Bharathiar University, Coimbatore.

ARUMUGAM S., MURTHY G.V.S. \& V.J. NAIR 2018. Taxonomic notes and lectotypification of Sporobolus tetragonus Bor (Poaceae, Chloridoideae). Phytotaxa 371(1): 67-69. https://doi.org/10.11646/phytotaxa. 371.1.9
BOR N.L. 1960. The grasses of Burma, Ceylon, India and Pakistan (excluding Bambuseae). Pergamon Press, London.

IUCN 2019. Guidelines for Using the IUCN Red List Categories and Criteria. Version 14. Prepared by the Standards and Petitions Committee. Available at: http:/ / ww w.iucnredlist.org/documents/RedList Guidelines.pdf (Accessed on 03.08.2021)

KABEER K.A.A. \& V.J. NAIR 2009. Flora of Tamil NaduGrasses. Botanical Survey of India, Kolkata.

KARTHIKEYAN S., JAIN S.K., NAYAR M.P. \& M. SANJAPPA 1989. Florae Indicae Enumeratio Monocotyledonae. Botanical Survey of India, Kolkata.

MOULIK S. 1997. The grasses and bamboos of India. Volume 2. Scientific Publishers, Jodhpur.

PETERSON P.M., ROMASCHENKO K., ARRIETA Y.H. \& J.M. SAARELA 2017. A molecular phylogeny of the subtribe Sporobolinae and a classification of the subfamily Chloridoideae (Poaceae). Memoirs of the New York Botanical Garden 118: 127-151. https://doi.org/ 10.21135/893275341.003

POWO 2021. Plants of the World Online. Facilitated by the Royal Botanic Gardens, Kew. Available at: http:// www.plantsoftheworldonline.org/ (Accessed on 03.08.2021).

PRASANNA P.V. 2019. Poaceae. In: LAKSHMINARASIMHAN P., DAS S.S., SINGH P., SINGH N.P., RAO M.K.V. \& P.S.N. RAO (eds.), Flora of Karnataka, Monocotyledons. Volume 3. Botanical Survey of India, Kolkata. pp. 527-804.

SREEKUMAR P.V. \& V.J. NAIR 1991. Flora of Keralagrasses. Botanical Survey of India, Kolkata. 